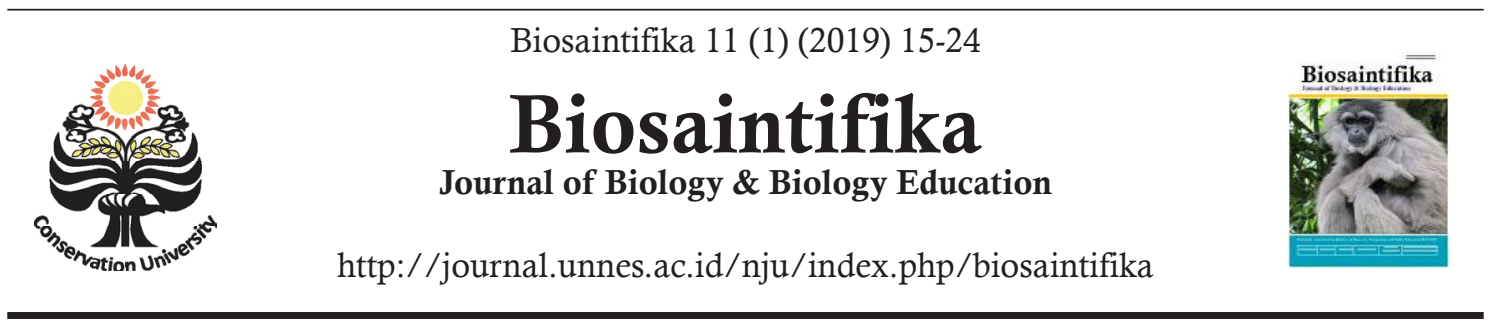

\title{
Pre-Release Assessment for Javan Gibbon (Hylobates moloch) in The Javan Gibbon Center, Mount Gede Pangrango National Park
}

\author{
${ }^{\square}$ Anton Ario $^{1,2}$, Agus Priyono Kartono ${ }^{3}$, Lilik Budi Prasetyo ${ }^{3}$, Jatna Supriatna ${ }^{2,4}$ \\ DOI: http://dx.doi.org/10.15294/biosaintifika.v11i1.14670 \\ ${ }^{1}$ Postgraduate of Tropical Biodiversity Conservation Study Program, Institut Pertanian Bogor, Indonesia \\ ${ }^{2}$ Conservation International Indonesia, Indonesia \\ ${ }^{3}$ Department of Forest Resource Conservation and Ecotourism, Institut Pertanian Bogor, Indonesia \\ ${ }^{4}$ Department of Biology, Universitas Indonesia, Indonesia
}

\section{History Article}

Received 13 June 2018 Approved 19 January 2019 Published 30 April 2019

\section{Keywords}

Assessment; Behavior; Javan Gibbon; Rehabilitation

\begin{abstract}
Preparation for gibbons before being released into their habitat is crucial. Thus, there is a need for readiness assessment of Javan gibbon with several criteria derived from other species of gibbons to determine individual readiness. Pre-release assessment study for Javan gibbon (Hylobates moloch) had been conducted in January February 2014, November - December 2014, and March-April 2016 in the Javan Gibbon Center, Mount Gede Pangrango National Park, West Java, Indonesia. The objective of this research was to assess the readiness of Javan gibbon behavior prior to release. Data collection was conducted by focal animal sampling method with 5-minute interval recording time and ad libitum method. The average time allocations of Javan Gibbon activities were as follow: feeding (18.17 $\pm 3.34 \%)$; moving $(22.34 \pm 0.53 \%)$; resting $(46.24 \pm 3.84 \%)$; socializing $(10.13 \pm 4.33 \%)$; sexual activity $(0.59 \pm 0.58 \%)$; and vocalizing $(2.54 \pm 0.88 \%)$. The similarities of activity allocation from this study compared by wild Javan gibbons data found as follows: feeding by $33.03 \%$, moving by $90.97 \%$, resting by $61.52 \%$, socializing by $38.09 \%$, vocalizing by $75.02 \%$, and sexual by $44.24 \%$. Based on readiness assessment of 11 Javan gibbons, 3 individuals were considered almost ready for release, while 8 individuals were considered ready. The assessment of behaviors criteria for the readiness of Javan gibbons before release has not existed before. The results of this research are important as a recommendation for the management of wildlife rehabilitation and as a guideline in implementing the rehabilitation and reintroduction program of Javan gibbons.
\end{abstract}

\section{How to Cite}

Ario, A., Kartono, A. P., Prasetyo, L. B., \& Supriatna, J. (2019). Pre-Release Assessment for Javan Gibbon (Hylobates moloch) in The Javan Gibbon Center, Mount Gede Pangrango National Park. Biosaintifika: Journal of Biology \& Biology Education, 11(1), 15-24. $11), 15-24$

Correspondence Author:

J1. Raya Dramaga, Babakan, Dramaga, Bogor, Jawa Barat 16680

p-ISSN 2085-191X

E-mail: aario@conservation.or e-ISSN 2338-7610 


\section{INTRODUCTION}

Javan gibbon (Hylobates moloch) is one of Java Island's endemic primate species. It is protected under Constitution No. 5 Year 1990 and by Government Regulation No. 7 Year 1999. It is included in International Union for Conservation of Nature and Natural Resources (IUCN) Redlist under Endangered Species category and also included in Appendix 1 in Convention on International Trade in Endangered Species of Wild Fauna and Flora (CITES) (Soehartono \& Mardiastuti, 2003; Nijman, 2006; Supriatna, 2006).

Javan gibbon poaching for the illegal trade is a serious threat to their survival in the wild. Generally, gibbons are captured whilst still young, often prior to weaning. The mothers are usually killed in order to capture a live infant or juvenile (Supriatna, 2006; Nijman, 2009).

Gibbons are not only sold in the black market, but in recent years there has also been rapid growth in online trading, especially on social media (Campbell et al., 2015). The sold gibbons are usually infants or juveniles, 6 months -2 years of age. They generally fetch anywhere between 3 to 5 million rupiahs per gibbon.

Efforts such as consistent and strict law enforcement and rescue, followed by rehabilitation and reintroduction programs are undoubtedly crucial. Before releasing gibbons to the wild, effective rehabilitation is important to optimize their behavioral ability as well as their health behavior that will support their successful adaptation to the wild.

Rehabilitation encompasses rescuing wildlife from the illegal trade and providing suitable conditions for physical and mental health as well as the development of appropriate survival skills to enable successful release and survival in the wild. Rehabilitation cannot replace the learning process in nature, however, gibbons have demonstrated that they can learn various behaviors required to survive in the wild (Cheyne, 2004).

The first Javan gibbon rehabilitation facility was established in 2003, which is the Javan Gibbon Center (JGC) located in Mount Gede Pangrango National Park (MGPNP). The Javan gibbon rehabilitation and reintroduction program was recommended after a series of meetings by national and international primate experts. Subsequently, a Population and Habitat Viability Analysis (PHVA) workshop was held in May 1994 in Cisarua, Bogor. This was followed by a Javan Gibbon Rescue and Rehabilitation Workshop in August 1997 in University of Indonesia, and the International Primatological Society
(IPS) congress in 2001 in Adelaide, Australia (Supriatna, 2006).

The rate of success for gibbon rehabilitation and release is relatively low, for the gibbons did not manage to pass behavioral ability criteria and the lack of post monitoring support. Prior to release, it is essential to ensure that the gibbons are demonstrating the behaviors and skills needed to survive in the wild. This can be assessed by fulfilling pre-release behavioral parameters (Cheyne 2004). Before beginning the reintroduction, it is recommended to use wild gibbon behavior as the principle of behavioral criteria to assess the rehabilitated gibbons (Cheyne et al. 2012).

Preparation for gibbons before being released into their habitat is crucial. Thus, there is a need for readiness assessment of Javan gibbon with several criteria derived from other species of gibbons to determine individual readiness. The purpose of research was to assess the readiness of Javan gibbon behavior prior to release. The results of research were expected to be a recommendation for the management of wildlife rehabilitation and as a guideline in implementing the rehabilitation and reintroduction program of Javan gibbons.

\section{METHODS}

\section{Time and Location of Study}

Research was conducted in JanuaryFebruary 2014, November-December 2014, and March-April 2016 at the JGC, MGPNP (Fig. 1). The research location was at $06^{\circ} 46^{\prime} 28.8^{\prime \prime}$ South latitude and $106^{\circ} 50^{\prime} 24.0^{\prime \prime}$ East longitude, $650 \mathrm{~m}$ above sea level. JGC aims to rehabilitate ex-pet Javan gibbon for release. JGC short term objective is to conduct behavioral and health assessment as well as improvement of behavior and health of Javan gibbon. The long-term objective is to reintroduce Javan gibbon into suitable habitat in accordance with IUCN translocation guidelines (Campbell et al., 2015). The last objective of their program is to consolidate Javan gibbon population in a habitat that support Javan gibbon's existence for long-term viability.

\section{Research Subject}

The subjects of this research were 11 Javan gibbons scheduled for release. The gibbons were a family Jowo-Bombom-Yani-Yudi, pair RobinMoni, pair Moli-Nancy, and family Mel-PoohAsri. The age level of observed gibbons consisted of 8 adults: Jowo, Bombom, Nancy, Moli, Moni, Robin, Mel, and Pooh ( $\pm 11-19$ years); one adolescent: Yani ( \pm 4 years), and 2 infants: Yudi $( \pm 1$ 
year) and Asri ( \pm 6 months) (Table 1$)$.

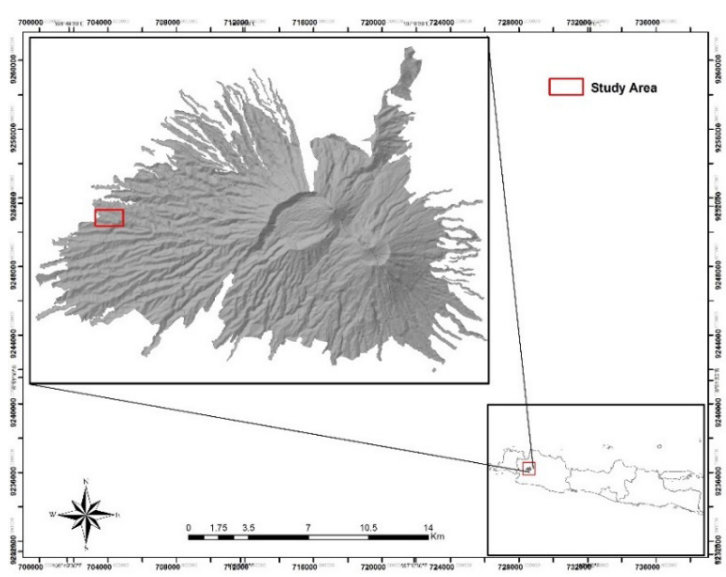

Figure 1. Map of study area

\section{Data Collection and Analysis}

Behaviors observed in this research consisted of feeding, moving, resting, socializing, sexual activity, and vocalization. Behavior data sampling utilized focal-animal sampling method, with 5 minutes intervals between observations, during gibbon active period from waking up in the morning until they sleep in the late afternoon (Cocks, 2000). Data sampling was also combined with ad-libitum method, by taking notes on important happenings outside the observation period (Martin \& Bateson, 2007).

In order to determine Javan gibbon pair bond, observation on proximity and distance between individuals within a group was decided as: (1) less than $1 \mathrm{~m}$ with contact, (2) less than $1 \mathrm{~m}$ without contact, (3) $1-5 \mathrm{~m}$, and (4) more than 5 $\mathrm{m}$. Cage strata usage pattern was also observed, it was separated into 4 regions: cage ground or terrestrial $(0-2 \mathrm{~m})$, strata 1 which is the lower part of the cage $(2-4 \mathrm{~m})$, strata 2 which is the middle part of the cage (4-6m), and strata 3 which is the upper part of the cage $(>6 \mathrm{~m})$.

There were 9 parameters in Javan gibbon behavioral readiness, which were the proportion of feeding, moving, resting, sexual activity, grooming, agonistic, solo female call (morning call), stereotypic, and human directed behavior. Javan gibbon behavioral readiness parameters used were a modification from behavioral readiness parameter proposed by Cheyne et al,. (2012) for Hylobates agilis. Every parameter was assumed to have different importance in supporting survival in the wild. Thus, in determining criteria and parameter value, behavior data from wild Javan gibbon was used based on literature study. According to Cheyne (2004), similar time allocation between those in rehabilitation center with the wild can be one of the indicators of the successful survival in the wild.

Obtained Javan gibbon behavioral data were analyzed by qualitative approach. Examination results were given score between 1, 3, and 5 and valued based on similarity between rehabilitated and wild Javan gibbon. Score analysis and value weighting were utilizing Likert scale. The use of every unit from every point was valid, for every option was an indicator of its represented variable (Budiaji, 2013). Javan gibbon readiness for release was divided into 3 categories: not rea$\mathrm{dy}$, with the total value of 100-233; almost ready with 234-366 and ready with 367-500.

\section{RESULTS AND DISCUSSION}

During 2003-2017, there were 48 pet Javan gibbons rehabilitated at the JGC (Fig.2). The

Table 1. The age level of observed Javan gibbons

\begin{tabular}{llllll}
\hline Nick Name & Sex & Ages Estimated & Rearing Phase & Rehabilitation Phase & Group status \\
\hline Jowo & M & \pm 15 years & $1999-2008( \pm 9$ years $)$ & $2008-2014( \pm 6$ years $)$ & \\
Bombom & F & \pm 15 years & $1999-2008( \pm 9$ years $)$ & $2008-2014( \pm 6$ years $)$ & Family \\
Yani & F & \pm 4 years & Birth at JGC & $2010-2014( \pm 4$ years $)$ & \\
Yudi & M & \pm 1 year & Birth at JGC & $2014( \pm 1$ year $)$ & \\
Nancy & F & \pm 16 years & $1998-2004( \pm 6$ years $)$ & $2004-2015( \pm 11$ years $)$ & Pair \\
Moli & M & \pm 12 years & $2002-2004( \pm 2$ years $)$ & $2004-2015( \pm 11$ years $)$ & \\
Moni & F & \pm 11 years & 2004-2005 $( \pm 1$ year $)$ & $2005-2015( \pm 10$ years $)$ & Pair \\
Robin & M & \pm 13 years & 2002-2008 $( \pm 6$ years $)$ & $2008-2015( \pm 7$ years $)$ & \\
Mel & M & \pm 19 years & $1997-2008( \pm 11$ & & \\
& & & years $)$ & $2008-2016( \pm 8$ years $)$ & \\
Pooh & F & \pm 17 years & 2000-2008 $( \pm 8$ years $)$ & $2008-2016( \pm 8$ years $)$ & Family \\
Asri & F & \pm 6 months & Birth at JGC & $2015-2016( \pm 1$ year $)$ & \\
\hline
\end{tabular}


age ratios of rehabilitated gibbons were: adult by $68.5 \%$, adolescent by $3.7 \%$, juvenile by $16.7 \%$ and infant by $11.1 \%$, with sex ratio was $54.17 \%$ male and $45.83 \%$ female. Based on historical data, the 48 Javan gibbons rehabilitated in JGC were taken from the wild with the following percentage: $2.08 \%$ between $1990-1993,2.08 \%$ between 1994-1997, 39.58\% between 1998-2001, 22.92\% between 2002-2005, 16.67\% between 2006-2009, $10.42 \%$ between $2010-2013$, and $6.25 \%$ between 2014-2017. The high percentage of poaching during 1998-2001 was most likely caused by the economic and political crisis in Indonesia which occurred in 1998. Deplorable economic conditions increased illegal activities, including Javan gibbon poaching within protected forest areas.

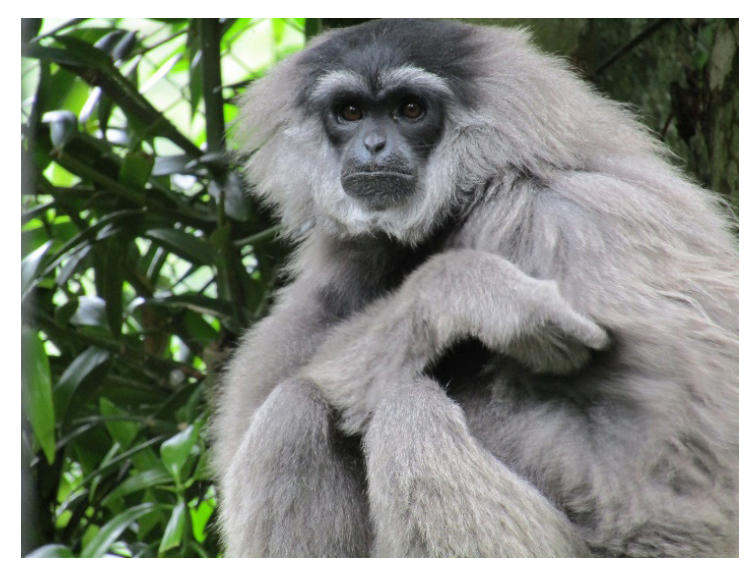

Figure 2. A Javan gibbon at JGC

\section{Activity budget of Javan gibbon}

Javan gibbon daily activity in JGC was recorded to begin in the morning at 6:00 a.m. and ended at 4:00 p.m. Total research observation hours were 285 hours for each observed Javan gibbon. The average daily activity was recorded to be 9 to 10 hours per day for each animal. Based on the analysis of behavioral data, it was found that all eleven observed Javan gibbons allocated their time as on Table 2.

The gibbons mostly ate fruits $(70.65$ $\pm 7.38 \%$ ), followed by leaves $(33.47 \pm 4.16 \%)$, in- sects $(1.22 \pm 0.97 \%)$ and none of them ate flowers $(0.00 \pm 0.00 \%)$. Brachiation $(59.88 \pm 20.22 \%)$ was the primary locomotion, followed by climbing $(15.83 \pm 10.17 \%)$, leaping $(12.45 \pm 7.68 \%)$, and bipedalism $(10.71 \pm 6.30 \%)$. They rested by sitting $(72.87 \pm 12.57 \%)$, lying $(26.84 \pm 12.65 \%)$, and sleeping $(0.29 \pm 0.31 \%)$. Social interaction among individuals was grooming $(60.41 \pm 7.37 \%)$, playing $(33.81 \pm 8.62 \%)$, and agonistic behavior (5.79 $\pm 2.34 \%)$. Sexual behavior between adults was as follow: courtship by $62.39 \pm 11.85 \%$, precopulation by $24.41 \pm 5.35 \%$, and copulation behavior by $13.19 \pm 12.67 \%$. The gibbons mostly vocalized by doing short call by $76.41 \pm 5.56 \%$, followed by morning call by $18.92 \pm 4.57 \%$, and alarm call by $4.67 \pm 0.17 \%$. Grooming, playing, and sexual activity are included in affiliative interaction among Javan gibbon. Average percentage behaviors for each gibbons group found as Figure 3.

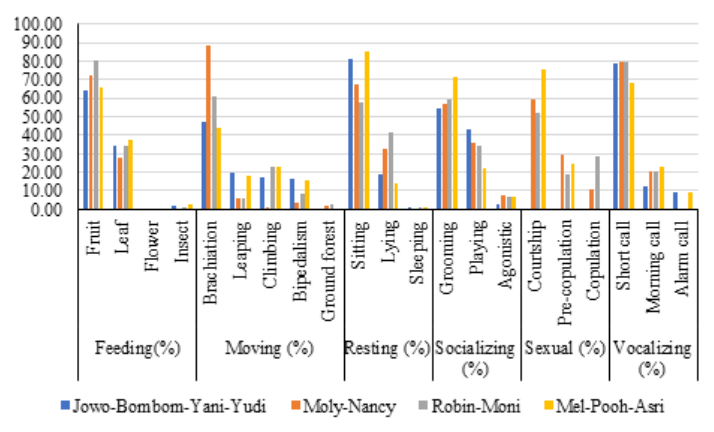

Figure 3. Average percentage for each gibbons group behavior

Figure 4 shows that the highest daily activity of 11 Javan gibbons was $11.99 \%$ at 11:00-12:00 a.m. and $11.86 \%$ at 1:00-2:00 p.m. In contrast, the lowest activity was $4.62 \%$ at 06:00-07:00 a.m. and $7.23 \%$ at 3:00-4:00 p.m.

The averages proximity among individuals in each group are as follow: $39.03 \%$ for $<1$ $\mathrm{m}$ with direct contact; $33.09 \%$ for $<1 \mathrm{~m}$ without contact; $24.97 \%$ for $1-5 \mathrm{~m}$; and $2.90 \%$ for $>5 \mathrm{~m}$. The average of cages strata used in each group as

Table 2. Behavioral time allocation percentage of each group of observed Javan gibbons

\begin{tabular}{llllll}
\hline \multirow{2}{*}{ Behaviors } & $\begin{array}{l}\text { The family of Jowo- } \\
\text { Bombom-Yani-Yudi }\end{array}$ & $\begin{array}{l}\text { The pair of } \\
\text { Moli-Nancy }\end{array}$ & $\begin{array}{l}\text { The pair of } \\
\text { Robin-Moni }\end{array}$ & $\begin{array}{l}\text { The family of } \\
\text { Mel-Pooh-Asri }\end{array}$ & \multirow{2}{*}{ Average (\%) } \\
\hline Feeding & $15.69 \pm 5.25$ & $21.13 \pm 1.60$ & $20.87 \pm 1.90$ & $14.88 \pm 5.63$ & $18.17 \pm 3.34$ \\
Moving & $22.86 \pm 2.65$ & $22.54 \pm 1.60$ & $12.33 \pm 1.83$ & $19.78 \pm 2.25$ & $22.34 \pm 0.53$ \\
Resting & $41.88 \pm 7.91$ & $46.95 \pm 0.89$ & $45.02 \pm 1.95$ & $51.08 \pm 4.27$ & $46.24 \pm 3.84$ \\
Socializing & $16.48 \pm 11.15$ & $6.75 \pm 2.22$ & $8.63 \pm 0.28$ & $10.45 \pm 2.50$ & $10.13 \pm 4.33$ \\
Vocalizing & $3.06 \pm 1.54$ & $1.77 \pm 1.05$ & $1.80 \pm 1.07$ & $3.50 \pm 1.51$ & $2.54 \pm 0.88$ \\
Sexual & $0.00 \pm 0.00$ & $0.72 \pm 0.43$ & $1.33 \pm 0.44$ & $0.30 \pm 0.27$ & $0.59 \pm 0.58$ \\
\hline
\end{tabular}


follow: $3.88 \%$ terrestrial part of the cage $(0-2 \mathrm{~m})$; $31 \%$ lower strata $(2-4 \mathrm{~m}) ; 53.65 \%$ middle strata (4$6 \mathrm{~m})$; and $7.36 \%$ upper strata $(>6 \mathrm{~m})$.

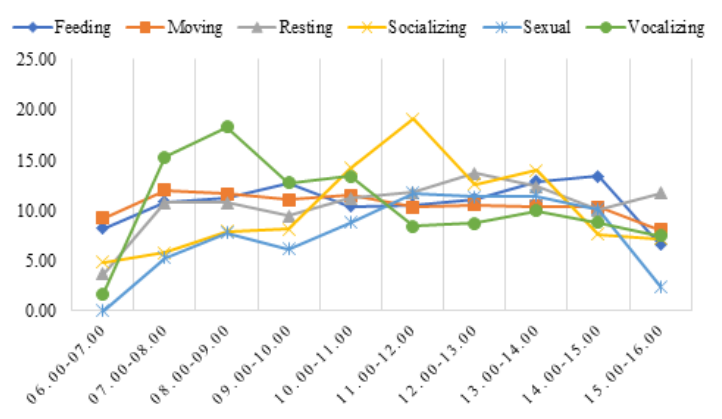

Figure 4. Daily activities pattern of pre-release Javan gibbons

The average highest daily time use were at 11:00-12:00 a.m. and 1:00-2:00 p.m. This is caused by the rising feeding and moving activity in the morning, also resting and social activity of Javan gibbon observed at JGC. Feeding activity increased in late afternoon to prepare for sleeping in the evening. The lowest activity was recorded on 6:00-7:00 a.m. and 3:00-4:00 p.m. This is because in the morning the gibbons were still resting after evening sleep. There was also no treatment yet by animal keeper to each Javan gibbon, including delivery of their morning feed at that time.

Javan gibbons started to increase their activity during feeding time. Feeding activity of Javan gibbons at the JGC happened during feeding time, which was at 7:00 a.m., 10:00 a.m., 12:00 a.m., and 2:00 p.m. These results showed that the bimodal pattern did not occur in the daily activity of Javan gibbons living at the JGC. Gibbons in the wild show daily activity with bimodal pattern, which means there are two peak hours for each activity. The first peak hours are reached after gibbons leave their sleeping trees and the second peak happens one hour before the group take their long rest (Ravasi, 2004).

Other than consuming market fruits (nonforest fruit), Javan gibbons at the JGC have been introduced to forest fruit since the beginning of rehabilitation process. The strategy of introducing forest fruits every morning was an effective way to make Javan gibbon eat forest fruits when they are hungry in the morning. Although it began by merely tasting, the gibbons eventually grew accustomed to forest fruit feed. There are 11 types of forest fruits that have been consumed by Javan gibbons at the JGC, which consist of: beunying (Ficus pistulosa), afrika (Maesopsis eminii), darangdang (Ficus sinuate), hampelas (Ficus hampelas), kondang (Ficus variegate), bareubeuy badak (Rapanea avenis), kokosan monyet (Dysoxylum aliaceum), hamirung (Vernonea arborea), walen (Ficus ribes), rasamala (Altingia excelsa), and jirak (Symplocos chonchinen).

The average percentage of fruit eaten was more than $50 \%$ and the rest of their intake consisted of leaves, flowers, and insects, showing that Javan gibbons during their rehabilitation process are already used to eating fruits. Javan gibbon's ability to find and consume forest fruit is important for their survival post-rehabilitation. As a frugivore, Javan gibbon consumed more fruits (61\%), compared to bud and young leaves (38\%), and flowers $(1 \%)$, coming from 125 types of plants in total. Javan gibbons also consumed several types of insects, such as termites (Supriatna \& Wahyono, 2000).

The average percentage of behavioral time allocation in 11 observed Javan gibbons were found to be similar with the percentages found in researches conducted by Kurniawati (2009) and Yohanna (2015) at the JGC. The average percentages obtained were feeding by $9.58-15.73 \%$, resting by $57.05-57.10 \%$, moving by $18.67-21.99 \%$, socializing by $1.6 \%-13.93 \%$, sexual activity by $0.58 \%$, and vocalizing by $2.35 \%$. However, these results show that there are some differences compared with wild Javan gibbons data.

\section{Behavior Similarity Level}

To comparing the time allocation of Javan gibbon at JGC, we used wild Javan gibbon data based on several studies on wild Javan gibbon behavior such as studies conducted by Kartono (2002), Fatimah (2012), Jao (2012), and Febrissa (2016) were conducted in Mount Gede-Pangrango National Park (MGPNP), Mount Halimun National Park (MHNP), and Leuweung Sancang Nature Reserve (LSNR), found as on Table 3.

The highest similarity was found in social behavior and the lowest was found in moving behavior both on infant. Infant aged less than six months is still together with mother, very rare seen trying to do self-playing. However, infant aged more than six months, already trying to do self-playing although keep around the mother. Playing behavior was mostly conducted by infant and juvenile in Mount Halimun Salak National Park (Iskandar, 2007). The high interaction caused by the presence of infant and juvenile also occurred in Jowo-Bombom-Yani-Yudi family and Mel-Pooh-Asri family, which increased grooming behavior from mother to infant and juvenile and also playing between infant and juvenile.

Similarity level on all of behavioral time 
Table 3. Percentage on similarity level data based on ages categorized on pre-release and wild Javan gibbons

\begin{tabular}{llllllllll}
\hline \multirow{2}{*}{ Behavior } & \multicolumn{4}{c}{$\begin{array}{c}\text { Wild Javan Gibbons } \\
\text { ( } \pm \text { SD) }\end{array}$} & \multicolumn{4}{c}{$\begin{array}{c}\text { Javan Gibbons at JGC } \\
( \pm \text { SD) }\end{array}$} \\
\cline { 2 - 10 } & Adult & Adolescent & Juvenile & Infant & Adult & Adolescent & Juvenile & Infant \\
\hline Feeding & $36.43 \pm 4.80$ & $36.66 \pm 6.75$ & $34.80 \pm 1.56$ & 3.44 & 49.87 & 33.15 & 28.92 & 42.17 \\
Moving & $20.78 \pm 9.32$ & $20.45 \pm 7.70$ & $17.00 \pm 1.77$ & 0.00 & 93.01 & 79.71 & 78.74 & 1.13 \\
Resting & $28.17 \pm 8.76$ & $28.52 \pm 10.65$ & $28.45 \pm 7.64$ & 82.28 & 60.92 & 69.41 & 69.12 & 67.50 \\
Socializing & $10.51 \pm 6.73$ & $8.90 \pm 8.86$ & $17.63 \pm 6.75$ & 13.28 & 96.34 & 46.85 & 80.57 & 97.23 \\
Vocalizing & $2.80 \pm 2.80$ & $5.46 \pm 0.36$ & $2.13 \pm 0.04$ & 0.56 & 90.36 & 33.92 & 40.02 & 6.68 \\
Sexual & $1.30 \pm 0.24$ & - & - & - & 45.38 & - & - & - \\
\hline
\end{tabular}

Table 4. Similarity level of observed and wild Javan gibbons based on behavioral time allocations

\begin{tabular}{lcccccc}
\hline \multirow{3}{*}{ Behavior } & \multicolumn{6}{c}{ Similarity level (\%) } \\
\cline { 2 - 7 } & $\begin{array}{c}\text { Wild Javan } \\
\text { Gibbons } \\
( \pm \text { SD) }\end{array}$ & $\begin{array}{c}\text { The family of } \\
\text { Jowo-Bombom- } \\
\text { Yani-Yudi }\end{array}$ & $\begin{array}{c}\text { The pair of } \\
\text { Moli- } \\
\text { Nancy }\end{array}$ & $\begin{array}{c}\text { The pair of } \\
\text { Robin- } \\
\text { Moni }\end{array}$ & $\begin{array}{c}\text { The fam- } \\
\text { ily of Mel- } \\
\text { Pooh-Asri }\end{array}$ & $\begin{array}{c}\text { Average } \\
(\%)\end{array}$ \\
\hline Feeding & $39.20 \pm 6.84$ & 40.05 & 54.13 & 53.23 & 37.95 & 33.03 \\
Moving & $24.56 \pm 11.29$ & 93.13 & 91.82 & 90.94 & 87.99 & 90.97 \\
Resting & $28.30 \pm 9.61$ & 67.56 & 60.27 & 62.85 & 55.41 & 61.52 \\
Socializing & $3.46 \pm 1.91$ & 21.00 & 51.18 & 40.09 & 40.09 & 38.09 \\
Vocalizing & $3.17 \pm 2.80$ & 96.51 & 56.09 & 56.88 & 90.58 & 75.02 \\
Sexual & $1.30 \pm 0.24$ & 0.00 & 56.15 & 97.74 & 23.08 & 44.24 \\
\hline
\end{tabular}

allocation data for each gibbons group found as on Table 4. Several studies on wild Javan gibbon behavior in Mount Gede-Pangrango National Park (MGPNP), Mount Halimun National Park (MHNP), and Leuweung Sancang Nature Reserve (LSNR) found that the average time allocation was: feeding by $39.20 \pm 6.84 \%$, moving by $24.56 \pm 11.29 \%$, resting by $28.30 \pm 9.61 \%$, socializing by $3.46 \pm 1.91 \%$, vocalizing by $3.17 \pm 2.80 \%$ and sexual activity by $1.30 \pm 0.24 \%$ (Fithriyani, 2007; Iskandar, 2007; Arifin, 2007; Malone, 2007; Ario, 2011).

Any differences similarity of behavioral allocation of Javan gibbon at JGC compared to wild Javan gibbon, caused by research area being limited to cages, that will be any limiting the natural behaviors of Javan gibbon. A difference in daily behavior time allocation were caused by different habitat condition (Kakati et al. 2009).

Highest similarity percentage was found in moving behavior, since every Javan gibbon has been placed in pair cage which has more room for moving space compared to quarantine and introduction cage. The gibbons can brachiate, leap, climb, and walk bipedally by using the movement tools such as ropes and bamboos. Brachiation movement has the highest percentage compared to leaping, climbing, and bipedalism movement. Pair cages at the JGC are triangular without internal separators, area of all sides was 42 $\mathrm{m}^{2}$ and the height was $7 \mathrm{~m}$. The triangular cage design was useful if aggression occurred between animals because the triangular angle can provide a safe retreat for the subordinate animal. Aggression may cause serious injuries, inflicted by Javan gibbon's canine teeth.

The high percentage of middle strata area usage in Javan gibbon activity is because the moving tools such as the ropes and bamboos are mostly placed in that strata. Placement of moving area in the middle strata can avoid the usage of lower strata or the cage floor space. Allowing Javan gibbon to use the lower strata is very risky as their activity would result in greater chance of predation after release. Grass and small plants were overgrown on the dirt ground of the cage to prevent the gibbons from going to the cage ground. The Javan gibbons at JGC were still seen using the cage ground to do some activities, although the average percentage is relatively low on $1.13 \%$. The use of lower strata of the cage may not exceed $5 \%$, as it will increase the risk of predation (Cheyne, 2004).

The lowest similarity percentage was found 
Anton Ario et al. / Biosaintifika 11 (1) (2019) 15-24

Table 5. The average percentage of every behavioral readiness parameter of Javan gibbon

\begin{tabular}{lccccccccc}
\hline \multirow{2}{*}{ Individual } & \multicolumn{10}{c}{ Behavior Parameter (\%) } \\
\cline { 2 - 10 } & $\mathrm{F}$ & $\mathrm{M}$ & $\mathrm{R}$ & $\mathrm{S}$ & $\mathrm{G}$ & $\mathrm{A}$ & $\mathrm{Mc}$ & $\mathrm{St}$ & $\mathrm{Hbd}$ \\
\hline Jowo & 20.78 & 19.66 & 50.56 & 0.00 & 5.63 & 0.25 & 0.00 & 0.00 & 0.00 \\
Bombom & 19.50 & 24.28 & 44.31 & 0.00 & 7.84 & 0.47 & 1.28 & 0.00 & 0.00 \\
Yani & 12.44 & 25.66 & 41.09 & 0.00 & 5.34 & 0.00 & 0.00 & 0.00 & 0.00 \\
Yudi & 10.06 & 21.88 & 31.59 & 0.00 & 5.65 & 0.15 & 0.00 & 0.00 & 0.00 \\
Moli & 22.26 & 21.42 & 46.32 & 0.42 & 3.64 & 0.90 & 0.00 & 0.00 & 0.00 \\
Nancy & 20.00 & 23.68 & 47.58 & 1.03 & 3.64 & 0.23 & 1.03 & 0.00 & 0.00 \\
Robin & 22.22 & 23.63 & 43.65 & 1.02 & 3.67 & 0.91 & 0.00 & 0.00 & 0.00 \\
Moni & 19.53 & 21.04 & 46.41 & 1.64 & 4.07 & 0.92 & 1.05 & 0.00 & 0.00 \\
Mel & 18.54 & 22.18 & 47.03 & 0.41 & 8.60 & 0.31 & 0.00 & 0.00 & 0.00 \\
Pooh & 17.95 & 19.42 & 50.67 & 0.50 & 6.77 & 1.44 & 0.72 & 0.00 & 0.00 \\
Asri & 8.16 & 17.73 & 55.54 & 0.00 & 5.67 & 0.00 & 0.00 & 0.00 & 0.00 \\
Remarks: F=feeding, M=-moving, $R=$ resting, S=sexual, G=grooming, A=Agonistic, & Mc=Morning call, \\
St=Stereotypic, Hdb=Human directed behavior & & & & & &
\end{tabular}

Table 6. Individual result of Javan gibbon pre-release behavioral assessment

\begin{tabular}{lcl}
\hline Individual & Total value & Categories \\
\hline Jowo & 368 & Ready (interval 367-500) \\
Bombom & 392 & Ready (interval 367-500) \\
Yani & 356 & Almost ready (interval 234-366) \\
Yudi & 312 & Almost ready (interval 234-366) \\
Moli & 382 & Ready (interval 367-500) \\
Nancy & 406 & Ready (interval 367-500) \\
Robin & 386 & Ready (interval 367-500) \\
Moni & 406 & Ready (interval 367-500) \\
Mel & 372 & Ready (interval 367-500) \\
Pooh & 372 & Ready (interval 367-500) \\
Asri & 330 & Almost ready (interval 234-366) \\
\hline
\end{tabular}

in feeding activity. This was caused during the rehabilitation phase, Javan gibbons obtained their food depending on the time food was given by animal keepers. Feeding activity of Javan gibbons at the JGC happened during feeding time, which was at 07:00, 10:00, 12:00, and 14:00.

\section{Javan Gibbon Individual Readiness}

From 9 behavioral parameters used to assess Javan gibbon behavioral ability, it was shown that feeding, moving, resting, grooming, and agnostic activity can be conducted by the 11 Javan gibbons with different allocation for each animal. Morning call activity was only done by adult female in every group, while stereotypic and human directed behavior was not shown by every individual (Table 5).

Based on 11 Javan gibbon behavioral readiness, 8 adults were within ready, while 2 juve- niles and 1 infant were almost ready for release (Table 6).

The highest parameter value in readiness was scored by adult females in the following order: Nancy, Moni, Bombom and Pooh. This is because of morning call behavior was only exist in adult female. The average morning call percentage was done by adult females of overall vocalization behavior. Morning call behavior prompted mutual reply from every cage at the JGC. The vocalization of pre-release Javan gibbon was also influenced by hearing the morning calls from wild Javan gibbon living in the surrounding forest, which made natural learning possible.

Morning calls by adult females are a territorial marking that shows that even if caged, the territorial system is very strong in every Javan gibbon group. A morning call vocalization by an adult female is a way to communicate with other 
groups and to show the range for her territory. This was in line with what was stated by Geissmann et al., (2005), that vocalization behavior in Javan gibbon exhibit unique characteristic compared to other Hylobatidae, in which the female has a larger role in protecting territory.

Other than the morning call, another important vocalization displayed by Javan gibbon is an alarm call by both male and female adults, which at times is followed by their offspring. Alarm calls were made whenever a potentially dangerous object or threat was observed by the group, such as wild boar, snake, or Javan leopard. This effort of warning the presence of threat by alarm calling was also followed by other animals in the groups at the JGC. Early warning is very important so that Javan gibbon can detect the possibility of threat such as leopard (Supriatna \& Wahyono, 2000). It would be a very beneficial skill upon release to the wild. Awareness is one of the purposes of living in group, for each member of the family has the role of detecting trouble/foreign objects in their surrounding environments. The functional role of every member of the family is to detect danger in their environment, allowing them to detect predators earlier (Tobing, 2002).

The average affiliative percentage value is higher compared to agonistic value. This showed that positive bonding has been formed between the members of Javan gibbon groups. Affiliative form observed were grooming, playing, and courtship. Sussman et al. (2004) in Asteria (2008) stated that interaction within groups consist of affiliative and agonistic interaction. Affiliative interactions are interactions that strengthen bond and improve relationship between members. Affiliative behavior in primates has the function of preserving pair-bonds and influencing other animal including courtship (Fuentes, 2002).

The lowest final value in individual readiness was found in infant and juvenile, in the order: Yani, Asri, and Yudi. This was caused by the age level which means there was still became behavioral limitation and they were still undergoing the learning process from their parents. Moreover, infants are still carried by the parent, although occasionally separated from the mother for selflearning.

Although infants and juvenile have lowest readiness value, the presence of strong bonds will allow them to be released along with the parents. Along with age growth, infants and juvenile will improve their natural behavior. Gibbons are not released individually, but rather as pairs or family units. Generally, in infant and juvenile, they tend to display playing behavior, as seen in family of Jowo-Bombom-Yani-Yudi and family of MelPooh-Asri. Generally, accepted release strategy for gibbons is to be released in well-bonded pairs, replicating their natural social structure (Campbell et al. 2015).

The 11 Javan gibbons observed did not exhibit any stereotypic behavior, even though upon arrival to the JGC several behaviors developed during their time as pets were still present. One such example was how adult male, Mel, who when arrived at the JGC in 2008 would often place his hand on his head repeatedly while sitting. With the time spent in rehabilitation process, these kinds of behaviors gradually subsided, especially after being paired and having offspring. The more activities Javan gibbon undertook, the more these kinds of stereotypic behaviors disappeared. Stereotypic behaviors likely developed as a result of long periods in confinement, while as illegal pets, they were unable to perform their natural behaviors.

Stereotypic behaviors are behaviors with a repetitive fixed movement pattern. This behavior often serves no definite function or clear purpose. Stereotypic behaviors are one of the indicators that an animal has been subjected to an unsuitable environment for a long period of time in captivity. Animals in captivity are prone to exhibit such behavior for the limited space for movement in the cages. Stereotypic behavior of no more than $3 \%$ can be eliminated by doing daily activities in nature (Cheyne, 2004).

Interest or desire to get close to animal keepers at JGC was not shown by the 11 soon to be released Javan gibbon. This is because during the rehabilitation process, interaction with human only occurred with keepers during feeding times or with veterinarian during health examinations. In the early period of rehabilitation, most gibbons still showed dependency on human presence just as they were when kept as pets. This dependency was shown in the form of attempted physical interaction while making low vocalization and extending hands towards human. Limiting direct interaction with humans is an effective method in eliminating these behaviors. Moreover, pairing Javan gibbon is also an effective way to reduce interest or dependency towards humans. The presence of a mate will allow them to interact more intensely with one another and eventually develop aggressive behavior to human as a defense mechanism for their mate or family member.

Javan gibbons that are kept as pets are often caged or tied to trees without any possibility of being active or able to reproduce. The long captivity period they have experienced often since 
infancy and up until adulthood causes their natural instinct to stop developing. Ex-pet Javan gibbon still have the ability to exhibit natural behavior and instinct but rehabilitation, activating and rekindling instinctive behavior is crucial.

Javan Gibbon Center is the first rehabilitation program of Javan gibbons in Indonesia. The lesson learned by another gibbon rehabilitation program that is Hylobates agilis in Central Kalimantan and Hylobates lar in Thailand, used in implementation of program at JGC. Therefore, the results of this study are an important finding as references for implementation and consideration in the overall assessment in the implementation of rehabilitation program. The result of research is expected to be used as follows a) can be inputted into guidance for implementation of rehabilitation and reintroduction of Javan gibbon including procedures, standards in rehabilitation process, translocation and reintroduction until post-release monitoring and evaluation, so that the program objectives can be achieved well; $b$ ) can provide an input to policy makers about the importance of conservation of Javan gibbons, especially wildlife management and their habitats for conservation and non-conservation areas managers.

\section{CONCLUSION}

Each animal treatment is included as behavior enrichment and limiting direct interaction with human is important in order to improve Javan gibbon behavior during rehabilitation period. Behavioral readiness of pre-release Javan gibbons need to be assessed especially for feeding, moving, resting, sexual, grooming, agonistic, morning call, stereotypic behavior, and human directed behavior. All 11 Javan gibbons are in 'almost ready" category which means that rehabilitation effort is beneficial for the 11 Javan gibbon that are scheduled for release.

\section{ACKNOWLEDGEMENT}

We thank Conservation International Indonesia, Javan Gibbon Foundation, Mount Gede Pangrango National Park, and Conservation Natural Resources of West Java. We would like to also thank Clare Campbell and Holly Thompson from Wildlife Asia and Silvery Gibbon Project, Arcus Foundation, which have supported the Javan gibbon rehabilitation at JGC. We thank the JGC team: Pristiani Nurantika, Iip Latipah Syaepulloh, Mulya Hermansyah, Khoerul Ridjwan, Suryadi, and Darus Salam.

\section{REFERENCES}

Arifin, S. (2007). Pola aktivitas harian owa jawa (Hylobates moloch Audebert, 1978) di hutan Rasamala Resot Bodogol Taman Nasional Gunung Gede Pangrango. [Undergraduate thesis]. Universitas Ibnu Khaldun, Bogor.

Ario, A. (2011). Aktivitas harian owa jawa (Hylobates moloch Audebert 1798) rehabilitan di blok hutan patiwel, Taman Nasional Gunung Gede Pangrango. Dalam: Kumpulan Hasil-hasil Penelitian Owa jawa di Bodogol Taman Nasional Gunung Gede Pangrango Periode 2000-2010. Ario A, Supriatna J, Andayani N (ed).13-29. Conservation International Indonesia. Jakarta.

Asteria. (2008). Interaksi sosial dalam kelompok Gorila (Gorilla gorilla Savage \& Wyman 1847) di Pusat Primata Schmutzer, Taman Margasatwa Ragunan. [Undergraduate thesis]. Universitas Indonesia, Jakarta.

Budiaji, W. (2013). Skala pengukuran dan jumlah respon skala Likert. Jurnal Ilmu Pertanian dan Perikanan, 2(2), 125-131.

Campbell, C. O., Cheyne, S. M. \& Rawson, B. M. (2015). Best Practice Guidelines for the Rehabilitation and Translocation of Gibbons. Gland, Switzerland: IUCN SSC Primate Specialist Group.

Cheyne, S. M. (2004). Assessing rehabilitation and reintroduction of captive-raised gibbons in Indonesia. [Doctoral dissertation]. University of Cambridge, Cambridge. xviii +231 .

Cheyne, S. M., Campbell, C. \& Payne K. L. (2012). Proposed guidelines for in situ gibbon rescue, rehabilitation and reintroduction. International Zoo Yearbook 46:1-17.

Cocks, LR. (2000). International Studbook for Silvery Gibbon (Hylobates moloch). Perth Zoo, Western Australia.

Fatimah, D.N. (2012). Aktivitas harian dan perilaku menelisik (grooming) owa jawa (Hylobates moloch Audebert, 1798) di Taman Nasional Gunung Halimun Salak, Provinsi Jawa Barat. [Undergraduate thesis]. Institut Pertanian Bogor, Bogor.

Febrissa, I. (2016). Aktivitas harian owa jawa remaja (Hylobates moloch Audebert, 1798) di Taman Nasional Gunung Halimun Salak, Provinsi Jawa Barat. [Undergraduate thesis]. Institut Pertanian Bogor, Bogor.

Fithriyani, U. (2007). Variasi pola pakan antar kelompok owa jawa (Hylobates moloch Audebert 1798) di Bodogol, Taman Nasional Gunung Gede Pangrango, Jawa Barat. [Undergraduate thesis]. Universitas Negeri Jakarta, Jakarta.

Fuentes, A. (2002). Patterns and trends in primate pair bonds. International Journal of Primatology 23(5): 953-978.

Geissmann, T., Bohlen, ES., Heuck, A. (2005). The male song of the Javan silvery gibbon (Hylobates moloch). Contribution to Zoology 74(1/2):1-25. 


\section{Anton Ario et al. / Biosaintifika 11 (1) (2019) 15-24}

Iskandar, S. (2007). Perilaku dan penggunaan habitat kelompok owa Jawa di hutan Rasamala Taman Nasional Gunung Gede-Pangrango. [Master's thesis]. Universitas Indonesia, Jakarta.

Jao, A. A. (2012). Dukungan masyarakat lokal dan habitat untuk konservasi owa jawa (Hylobates moloch Audebert, 1798) di Resort Bodogol Taman Nasional Gunung Gede Pangrango. [Master's thesis]. Institut Pertanian Bogor, Bogor.

Kakati, K.R., Raghavan, R., Chellam, Q.Q., Chivers, D.J. (2009). Status of western hoolock gibbon (Hoolock hoolock) populations in fragmented forest of Eastern Assam. Primate Conservation 24:1-11.

Kartono, A.P., Prastyono., Maryanto, I. (2002). Variasi aktivitas harian Hylobates moloch (Audebert, 1798) menurut kelas usia di Taman Nasional Gunung Halimun, Jawa Barat. Berita Biologi 6(1):67-73.

Kurniawati, N. (2009). Pengamatan aktivitas harian pasangan owa jawa (Hylobates moloch Audebert) di Javan Gibbon Center, Taman Nasional Gunung Gede Pangrango, Jawa Barat. [Undergraduate thesis]. Universitas Indonesia, Jakarta.

Malone, N.M. (2007). The socioecology of the critically endangered Javan gibbon (Hylobates moloch);
Assessing the impact of anthropogenic disturbance on primate social systems. [Doctoral dissertation]. University of Oregon, Portland.

Martin, P., Bateson, P. (2007). Measuring behavior: An introductory guide. $3^{\text {rd }}$ ed. Cambridge University Press, Cambridge.

Nijman, V. (2006). In-situ and ex-situ status of the Javan Gibbon and the role of zoos in conservation of the species. Contributions to Zoology 75(3/4): 161-168.

Nijman, V. (2009). Saved from trade: Donated and confiscated gibbons in zoos and rescue centers in Indonesia. Endangered Species Research 9: 151-157.

Ravasi, D. (2004). Phuket's forest sings again. The Gibbon Rehabilitation Project, Phuket. Thailand.

Soehartono, T., Mardiastuti, A. (2003). Pelaksanaan Konservasi CITES di Indonesia. Jakarta: JICA

Supriatna, J., Wahyono, EH. (2000). Panduan Lapangan Primata Indonesia. Yayasan Obor Indonesia. Jakarta.

Supriatna, J. (2006). Conservation programs for the endangered Javan Gibbon (Hylobates moloch). Primate Conservation 21: 155-162.

Tobing, I.S.L. (2002). Respon primata terhadap kehadiran manusia di kawasan Cikaniki, Taman Nasional Gunung Halimun. Berita Biologi. 6 (1): 99-105. 